\title{
FORMAL DEFINITIONS OF TYPE MINERAL SPECIMENS
}

\author{
PETE J. DUNN* \\ Department of Mineral Sciences, Smithsonian Institution, Washington, D.C. 20560, U.S.A. \\ JOSEPH A. MANDARINO** \\ Department of Mineralogy and Geology, Royal Ontario Museum, 100 Queen's Park, Toronto, Oñtario M5S 2 C6 \\ and Department of Geology, University of Toronto, Toronto, Ontario MSS IAI
}

\section{INTRODUCTION}

Type mineral specimens are reference samples for the definition of mineral species. The biological sciences have a long-established system of type specimens, but the formal designation of such samples is a relatively recent matter in mineralogy. Indeed, for a vast number of minerals, some first discovered in antiquity, and many others discovered as recently as this century, there exist no type specimens at all. In many such cases, the best available information comes from designations such as "original material" on museum catalogues, and on some old labels. Interpretations of labels, however, even if they are in the handwriting of the original describer, should always be treated with utmost caution.

Embrey \& Hey (1970) provided a thoughtful discussion of the problems associated with type specimens, and the practices of our colleagues in the biological sciences, and proposed an argument for distinguishing seven kinds of type specimens. We recommend a reading of their text for a perspective on the matter.

The effort of Embrey \& Hey (1970), intended as a discussion paper, did much to generate informal debate and discussion within the curatorial community. Some of the type designations suggested by Embrey \& Hey (holotype, cotype, and neotype) were rather widely accepted. The Commission on Museums (CM) had (circa 1976-78) adopted, in part, these definitions as the background basis for the CM project on the listing of type specimens. Unfortunately, in the compilation of data for this project, only a few curators used this suggested nomenclature. The lack of formal, rigorous definitions, and the absence of international adoption, or even the sanction of professional societies, made use of these terms inconsistent at best, and contradictory at worst.

Accordingly, the definitions presented here were drafted and circulated to the Commission on New Minerals and Mineral Names, International Mineralogical Association (IMA), and to the Commission on Museums, IMA, for discussion and consideration. After a review period, they were revised, and recirculated to both Commissions for formal voting. The following statements and definitions, in italics, were approved by both Commissions.

\section{Nomenclature Designations for Type Mineral Specimens}

The following kinds of type specimens are those accepted and approved by the Commission on New Minerals and Mineral Names and the Commission on Museums of the International Mineralogical Association. It is emphasized that the designation of type material of a mineral species is the responsibility of the senior author of the original description of that species. In the case of "old" species for which no types were designated by the senior author, qualified, tentative designations may be given by the curator(s) having custody of the originally studied material. It is most important that in cases such as this, the curator acts with the utmost responsibility and caution. If there is any doubt that certain material represents the material originally described, no type designation should be conferred. Curatorial designations are not binding on the Commissions; they may be revised if controversy requires their review. In such cases, review will be by the Commission on Museums, IMA.

\footnotetext{
*U.S.A. member, Commission on New Minerals and Mineral Names, International Mineralogical Association.

**Chairman, Commission on New Minerals and Mineral Names, International Mineralogical Association.
} 


\section{DEFINITIONS}

Holotype: a single specimen (designated by the author) from which all the data for the original description were obtained. Where portions of such a specimen have been sent to other museums for preservation, the author will designate each of these as "part of the holotype."

Cotype: specimens (designated by the author) as those used to obtain quantitative data for the original description. Specimens examined only visually should not be considered cotypes.

- Netype: a specimen chosen by the author of a redefinition or re-examination of a species to represent the species when the holotype or cotypes cannot be found. It must be shown that every attempt has been made to locate the originally described material. Neotypes can also be designated when examination of all holotypes and cotypes has shown that the definitive unit-cell parameters and chemical composition cannot be experimentally determined. All neotypes require the approval of the Commission on New Minerals and Mineral Names of the International Mineralogical Association.

Both holotypes and cotypes are possible, and even advantageous, for a mineral species. The use of "holo" here is to indicate that all of the necessary data were obtained from the holotype specimen. If the author of a new mineral description chooses to designate additional samples as cotypes, this is permissible. Such cotypes are designated only if they were used to obtain quantitative, but not necessary, data. Thus, a mineral species may be represented by a holotype and one or more cotypes and/or neotypes.

\section{DisCUSSION}

We present some examples to illustrate these definitions:

Mineral $A$ was described in such a manner that all the necessary data were obtained from one specimen; that specimen is the holotype.

Mineral $B$ could be defined only if more than a single specimen were used to provide the necessary quantitative data. These specimens are cotypes, and there is no holotype.

Mineral $C$ was defined by data derived from a single specimen which is, of course, the holotype. If additional data which were not necessary to define the species were obtained from other specimens, these additional specimens are cotypes. These cotypes might have provided data to indicate the variability of the chemical, optical, crystallographic or other data for the species.

Mineral $D$ required redefinition, but none of the original type material could be found. In such cases, a neotype specimen may be designated by an investigator, but only with approval of the Commission on New Minerals and Mineral Names, IMA.

Investigators are encouraged to deposit all type specimens in non-private, institutional, professionally curated, research-oriented museums, and to clearly designate the type status of each specimen, using the definitions presented here. Responsible scientists are encouraged to deposit such material directly with the museum, and not employ non-scientists or commercial dealers as intermediaries.

\section{REFERENCES}

Embrey, P.G. \& Hey, M.H. (1970): Type specimens in mineralogy. Mineral. Record 1, 102-104. 